\title{
Pensononowoor
}

2015, vol. 73, 3-10

http://dx.doi.org/10.12657/denbio.073.001

\author{
Anna Gazda, Stanistaw Miścicki, Kazimierz Chwistek
}

\section{Tree species diversity and above-ground biomass of natural temperate forest: montane versus lowland forest}

Received: 31 July 2013; Accepted: 17 June 2014

\begin{abstract}
We studied the relationship between tree-species diversity and the above-ground biomass on an example of two natural Polish forest with different altitiudinal range, plant species pool, vegetation and climatic conditions. The study sought to determine whether: (1) above-ground biomass in natural forests correlates with tree-species diversity irrespective of the kind of forest (montane or lowland), and (2) the relationship in question is negative, (3) the above-ground biomass is greater in montane forests than in lowland ones.
\end{abstract}

Natural forests present in $1^{\circ}$ Polish Gorce Mountains (montane forest) alongside comparable data for the $2^{\circ}$ world-renowned lowland forest that is present in the Białowieża National Park. Data were collected within 558 sample plots (á 200-square-metre). The diameter at breast height of all trees with girths of or exceeding $12 \mathrm{~cm}$ was measured. To compute above-ground biomass we calculated dry masses for each tree on the basis of values for $\mathrm{dbh}$ and height, next we summed these values for all species present within each plot. The number of tree species on a plot ranged from only one (mainly in spruce stands) to six (in mixed deciduous lowland forest stands). The above-ground accumulated biomass ranged from 6 to 1155 (average

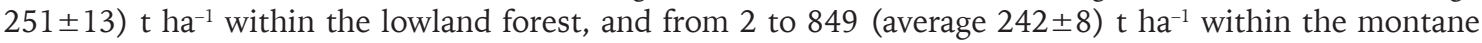
forest.

We concluded that there was a humped-back shaped relationship between tree-species diversity and aboveground biomass in both lowland and montane natural forests.

Additional key words: above-ground biomass, altitudinal gradient, species richness-productivity relationship, Simpson's species diversity index

Addresses: A. Gazda, Department of Forest Biodiversity, Institute of Forest Ecology and Silviculture, University of Agriculture, 31-425 Kraków, Poland, e-mail: rlgazda@cyf- kr.edu.pl

S. Miścicki, Department of Forest Management, Geomatics and Forest Economics, Warsaw University of Life Sciences, 02-787 Warszawa, Poland, e-mail: Stanislaw.Miscicki@wl.sggw.pl K. Chwistek, Gorce Mountains National Park, 34-735 Niedźwiedź, Poland, e-mail: kazimierz.chwistek@gorcepn.pl 


\section{Introduction}

The issue of the relationship between aboveground biomass and species diversity has been discussed for many years. At first, scientists tried to describe this relationship by fitting different models to collected data. Next, some tried to predict results for this relationship on a global scale, in order to be able to predict changes in plant distribution, the species composition of different communities or carbon sequestration (Mittelbach et al. 2001, 2003; Whittaker et al. 2001, 2003; Rahbek 2005; Jacob et al. 2010). Some researchers came to regard the relationship between above-ground biomass and species diversity as a negative one (Waide et al. 1999; Mouquet et al. 2002; Chen et al. 2003; DeClerck et al. 2005), while others found a positive one (Caspersen et al. 2001; Vilà et al. 2007), unimodal like U-shaped ones, a humped-back shaped processes (Mittelbach et al. 2001), or simply no relationship (Szwagrzyk and Gazda 2007b; Whittaker 2010). All studied forests differed in terms of climatic features and geographical location (biome, latitude and altitude). Climatic variables are probably of greatest importance where species richness and the altitudinal gradient are concerned (Currie and Paquin 1987; Currie 1991; Boucher-Lalonde et al. 2012). Beyond that, there is the very important relationship between species richness and productivity (Jacob et al. 2010; Chisholm et al. 2013; Belote and Aplet 2014). Higher productivity is usually associated with a greater number of individuals and/or greater total biomass of tree species in a forest (Keeling and Phillips 2007). Primary productivity resembles species richness in mainly being affected by temperature and precipitation (Nogués-Bravo et al. 2008; McCain et al. 2010).

Research conducted in Central Europe, studying 24 mainly montane, lower montane upland and lowland natural forests (Szwagrzyk and Gazda 2007a), showed that the mean biomass per unit area in the Białowieża National Park (lowland forest) was one of the lowest, even as the diversity was the greatest of all. This allowed for the advancement of a hypothesis, set out in the cited paper (Szwagrzyk and Gazda 2007a), that:

- the above-ground biomass in natural forests is correlated with tree-species diversity irrespective of the kind of forest,

- the relationship in question is a negative one,

- the above-ground biomass is greater in montane forests than in lowland ones.

The aim of the work described here was thus to test the above, several-element hypothesis, whose verification was sought by means of a comparison between the natural lowland forest present in the Białowieża National Park (BNP) and the natural montane forest occurring in the Gorce Mountains
National Park (GMNP) of the Western Carpathians. In line with the hypothesis concerning the greater biomass in montane forest, it was suggested that the greatest biomass in the BNP is associated with the presence of pedunculate oak Quercus robur, while the greatest in the GMNP is due to the presence of silver fir Abies alba, mainly due to features of its strategy and architecture (Bolibok et al. 2000; Giel et al. 2001; Holeksa et al. 2009).

\section{Materials and Methods}

\section{Study sites}

The natural forest in the Strict Reserve of the Białowieża National Park, which covers 4747 ha in total (4584 ha under forest) was one of two objects studied. It is situated in the central part of the Białowieża Primeval Forest and its position is given by the coordinates $52^{\circ} 42^{\prime}-52^{\circ} 47^{\prime} \mathrm{N}, 23^{\circ} 49^{\prime}-23^{\circ} 56^{\prime} \mathrm{E}$. In 1921, the area of this forest that had been least destroyed and transformed, containing diverse stands, was made subject to protection in the BNP. The forest is located in the temperate transitional zone, with a prevalence (depending on the year) of continental over Atlantic influences (Faliński 1986). Average annual values for the major climatic variables are: $6.8^{\circ} \mathrm{C}$ in the case of mean air temperature, and $641 \mathrm{~mm}$ for annual precipitation. The terrain is flat and altitudes in the range $147-170 \mathrm{~m}$ a.s.l. The three most widespread forest assemblages are:

1. The lowland community of Tilio-Carpinetum typicum oak-hornbeam forest - accounting for ca $40 \%$ of the BNP's forest area - in which stands are dominated by pedunculate oak (Quercus robur), followed by hornbeam (Carpinus betulus) and Norway spruce (Picea abies), plus admixture species like the abundant small-leaved lime (Tilia cordata) and maple (Acer platanoides).

2. The lowland community of Calamagrostio arundinaceae-Piceetum oak-pine-spruce forest that occupies $c a 11 \%$ of the area and has stands consisting mainly of oak, Scots pine (Pinus sylvestris), Norway spruce, with admixture of silver birch (Betula pendula).

3. The community of (Circaeo-Alnetum) riparian forest, which covers $c a 9 \%$ and has stands consisting mainly of black alder (Alnus glutinosa) and European ash (Fraxinus excelsior).

The GMNP - the second studied object - was established in 1981, as the fifth Park to protect areas of the Polish Carpathian Mountains. Its total area equaled 7010 ha (6591 ha under forest) and occupies the central part of the Gorce Mountains (49 $26^{\prime}-$ $49^{\circ} 40^{\prime} \mathrm{N}, 19^{\circ} 53^{\prime}-20^{\circ} 26^{\prime} \mathrm{E}$ ), which form part of the range known as the Western Beskids. This is nevertheless a well-separated mountain range of area 550 
$\mathrm{km}^{2}$ and altitudes in the range $375-1311 \mathrm{~m}$ a.s.l. The whole mountain massif is characterized by gentle surface features and flattened mountain ridges. Only stream valleys display markedly developed surface features with numerous steep inclines, landslides and inliers. The climate of the Gorce Mountains is characterized by zones reflecting differences in altitude, exposure and slope. The average temperature in a year is $6-7^{\circ} \mathrm{C}$ at the foot of the mountains, and $c a$ $3^{\circ} \mathrm{C}$ in upper regions near the mountain crests. Of a similar nature is the distribution of rainfall, which increases with altitude from $750-800 \mathrm{~mm}$ to 1200 $\mathrm{mm}$ a year. Within the GMNP, there are two zones of vegetation:

- the lower subalpine zone at altitudes in the range 600-1150 $\mathrm{m}$ a.s.l.,

- the upper subalpine zone covering higher sections of mountain ridges above $1150 \mathrm{~m}$ a.s.l.

The three best-preserved and most widespread forest communities are:

1. The lower subalpine community of Dentario glandulosae-Fagetum (Fagetum carpaticum) beech forest - accounting for ca $62 \%$ of the GMNP's forest area - in which stands are dominated by European beech (Fagus sylvatica), followed by silver fir (Abies alba), which is almost as abundant, and the less well-represented Norway spruce (Picea abies), plus admixture species like the abundant sycamore (Acer pseudoplatanus), as well as the occasionally-present Wych elm (Ulmus glabra).

2. The lower subalpine community of silver fir and Norway spruce (Abieti-Piceetum) that occupies $c a 11 \%$ of the area and has stands consisting mainly of Norway spruce and silver fir.

3. The upper subalpine spruce community (Plagithecio-Piceetum), which covers ca $17 \%$ of the whole area and mainly comprises monotypic forest stands dominated by Norway spruce.

The distance between the BNP and the GMNP is of about $400 \mathrm{~km}$.

\section{Data collection}

In the BNP 160 permanent sample plots were established, these forming a grid with average side lengths of $267 \times 1067$ meters, with the shorter side oriented roughly to an $86^{\circ}$ azimuth. The GMNP in turn featured 398 permanent plots in a grid of $400 \times$ 400 metres with one side oriented to a $0^{\circ}$ azimuth. Within each sample plot (of 200 square metres) each tree was identified to species level and the diameter at breast height (dbh) measured (in the case of all trees with $\mathrm{dbh}>12 \mathrm{~cm}$ ), along with heights. Comparisons between sites were based on results obtained in 2002.

\section{Data analysis}

To compute above-ground biomass we calculated dry masses for each tree on the basis of values for dbh and height. Volume and average dry-wood weight (Krzysik 1974) were then estimated, followed by the amount of dry mass accumulated by each species within a sample plot. Next we summed these values for all species present within each plot to evaluate above-ground biomass. On the basis of the proportional presences of different species, the Simpson's index of species diversity D (Krebs 1994) - as set against the above-ground biomass for each plot - was calculated, using the formula:

$$
D=1-\sum_{i=1}^{S}\left(p_{i}^{2}\right)
$$

(where $p_{i}$ is the proportion of species $i$ in a sample plot and $S$ the number of species). This index is more informative measure of diversity in comparison with value of a species richness. It takes into account both number of species and its abundance within a study area (Magurran 2004)

A rank abundance curve was drawn to provide more information on species richness and evenness of these two different forests, and to compare these species abundance patterns of both lowland and montane natural forests. Relative species abundance was calculated in terms of species basal area $\left(\mathrm{BA} \mathrm{m}^{2}\right)$ in relation to other species occurred within given study area. Multivariate regression was used to calculate the relationship between $D$ (the dependent variable), elevation ( $E$; transformation $E^{\prime}=\log (1300$ - E) was applied), above ground biomass (AGB), their squares, third powers (to give the possibility of using an asymmetric regression line), and the categorical variable 'object' (BNP and GMNP). The set of independent variables was determined on the basis of the backward removal method. Additionally, to assess whether the proper model was chosen, regression lines depicting the adjusted $D^{\prime}$ were compared with the moving average lines for particular objects. The method of 'moving averages' is often used to estimate trends (Legendre P. and Legendre L. 2012). Given a sequence (ordered set of objects) an $n$-moving average is a new sequence defined from the $a_{i}$ by taking arithmetic mean of subsequences of $n$ terms:

$$
s_{i}=\frac{1}{n} \sum_{j=i}^{i+n-1} a_{j}
$$

Analysis of covariance was used to evaluate whether population means of a dependent variable $D$ were equal across levels of a categorical independent variable 'object'. 
A logistic function:

$$
F=1 /\left(1+\exp \left(b_{0}+b_{1} \cdot A G B\right)\right)
$$

was used to calculate the relationship between the share accounted for by a particular tree species $(F)$ and $A G B$ in the given sample plot. All calculations were made using STATISTICA 8 (StatSoft, Inc.).

\section{Results}

The numbers of tree species on given plots ranged from just one (mainly in spruce stands) to six (in mixed deciduous lowland forest stands). Sample plots thus ranged from the monospecific (in $30 \%$ of cases in the GMNP; $7.5 \%$ in the BNP) to multi-species (GMNP - maximum five tree species; BNP maximum six). It was most typical for monospecific stands in the GMNP to be formed by Norway spruce (19\%) or European beech (9\%), while in the BNP the rather few plots with just a single species had hornbeam (in $2.5 \%$ of cases), birch Betula spp. (2\%), Norway spruce $(2 \%)$, small-leaved lime $(0.6 \%)$ or black alder $(0.6 \%)$. A high share of monospecific spruce stands in the GMNP was influenced by site condition, as 17 per cent of plots were located in the rather poor subalpine forest sites.

The two forests were of similar significance where species richness (recorded in all plots taken together) was concerned, since 11 tree species were present in the GMNP and 13 in the BNP (Fig. 1). However, the most abundant tree species in the montane forest (of the GMNP) were limited to three, while in the BNP's lowland forest as many as eight were at times

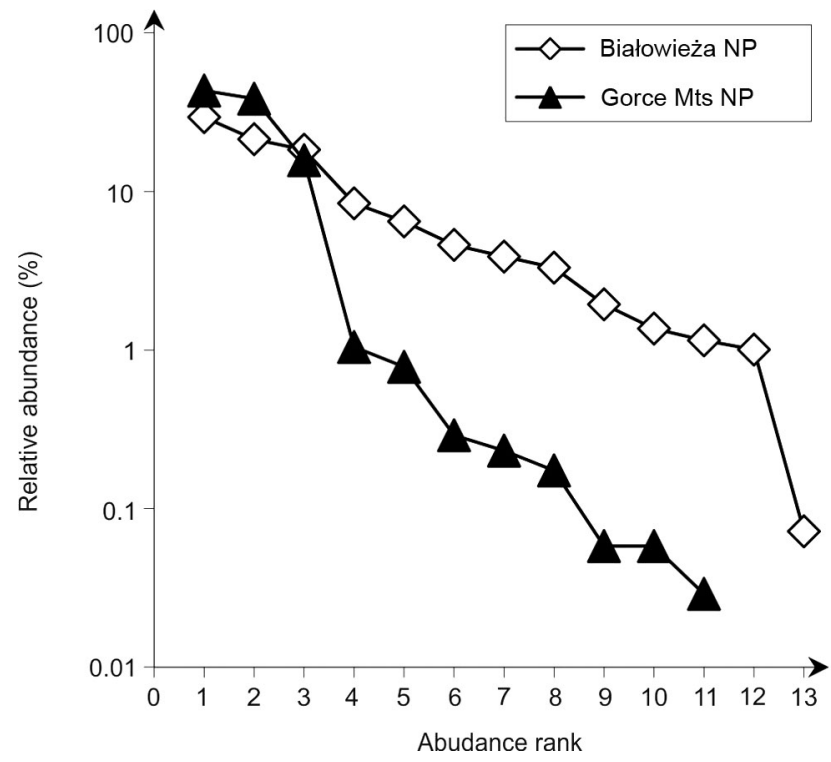

Fig. 1. Rank abundance curves for tree species in montane forest (the Gorce Mountains National Park) and lowland forest (the Białowieża National Park)

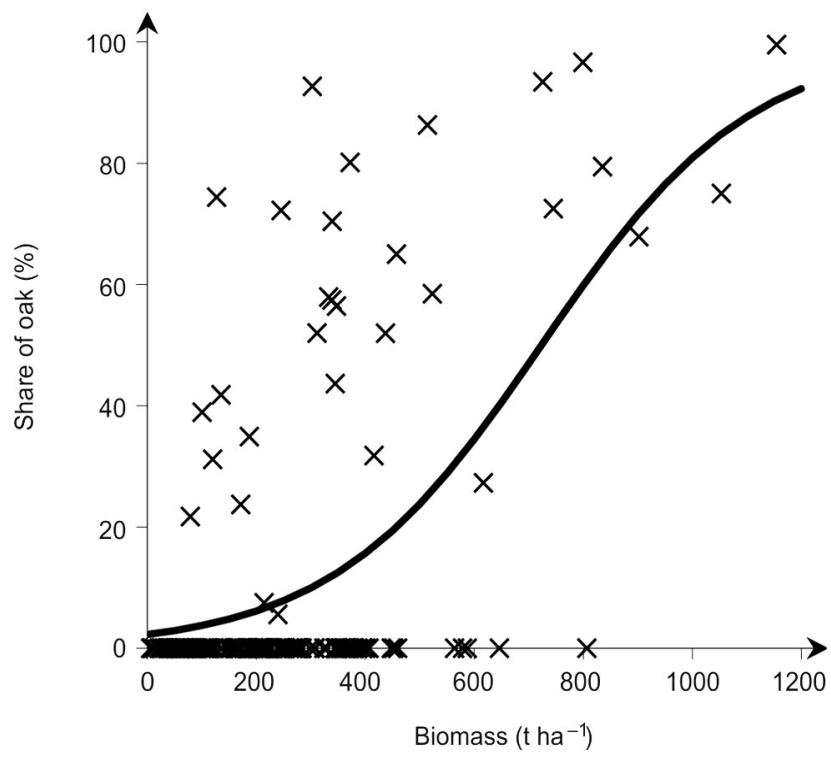

Fig. 2. Share of oak in relation to above-ground biomass in sample plots in the Białowieża National Park $((y=1)$ $\left.(1+\exp (3.77-0.00521 x)), R^{2}=0.35, \mathrm{P}<0.001\right)$

present in abundance (more than 3 per cent of each). The latter sites were thus characterized by greater evenness between species, there being considerable diversity both within and among stands.

$A G B$ (dry mass) accumulations ranged from 2 to $849 \mathrm{t} \mathrm{ha}^{-1}$ (average $242 \pm 8, C I$ at $\mathrm{P}=0.05$ ) in the GMNP and from 6 to $1155 \mathrm{t} \mathrm{ha}^{-1}$ (average $251 \pm 13$ ) in the BNP. The stands that were most productive were dominated by pedunculate oak in the case of the BNP (the species was absent altogether from the GMNP) (Fig. 2), and by European beech in the case of the GMNP (the BNP in turn lying well outside the natural range of this species) (Fig. 3).

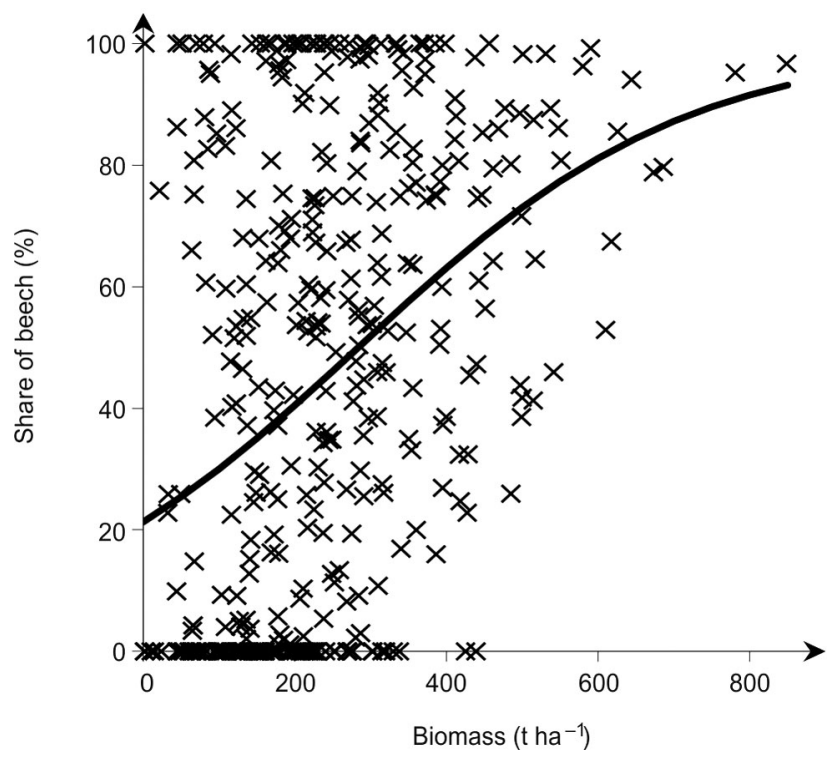

Fig. 3. Share of beech in relation to above-ground biomass in sample plots in the Gorce Mountains National Park $\left(y=1 /(1+\exp (1.31-0.00461 x)), R^{2}=0.15, \mathrm{P}<0.001\right)$ 


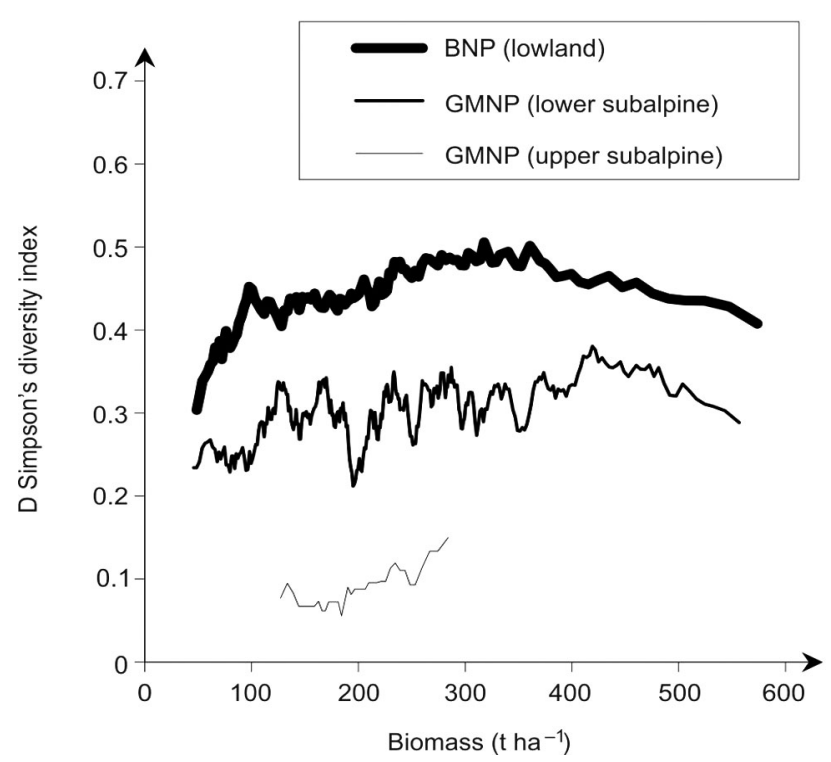

Fig. 4. A 30-observation moving average line of the Simpson's species diversity index in relation to above-ground biomass in the Białowieża National Park, lower and upper subalpine zones of the Gorce Mountains National Park

Values for the $D$-index varied from 0 (on 115 plots in the GMNP and 12 in the BNP) to 0.66 (GMNP) or 0.77 (BNP). As showed the moving average (Fig. 4) $D$ reached a maximum point when $A G B$ was about ca $360 \mathrm{t} \mathrm{ha}^{-1}$ (BNP lowland forest) and ca $420 \mathrm{t} \mathrm{ha}^{-1}$ (GMNP lower subalpine forest). Analysis of covariance revealed that $D$ was influenced by variables (eq. 3): $E(\mathrm{P}<0.001), A G B(\mathrm{P}<0.001)$ and $A G B^{3}$ $(\mathrm{P}<0.001)$. Means of the dependent variable $D$ were

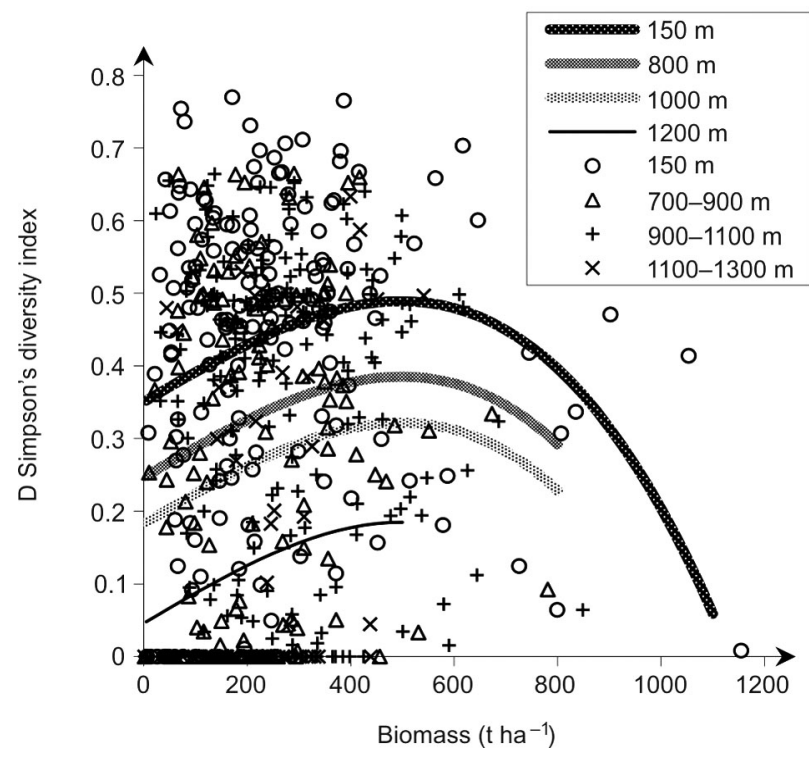

Fig. 5. Relationship between values for Simpson's species diversity index, above-ground biomass and elevation; lines represent smoothed results for different altitudes, points represent results from sample plots classified to the altitudinal zones. equal across levels of the categorical independent variable 'object' (i.e. GMNP or $\mathrm{BNP}, \mathrm{P}=0.57$ ). The model for the Simpson's index of species diversity $D$ was as follows:

$$
D=-0.53+4.2 \times 10^{-4} \times A G B-5.7 \times 10^{-10} \times A G B^{3}+
$$
$0.29 \times \log _{10}(1300-E)$

The coefficient of determination $R^{2}$ equaled 0.18 $(\mathrm{P}<0.001)$.

Species diversity was greater in the lowland natural forest than in the montane, though biomass was only slightly greater (Fig. 5). On the basis of the above model, the adjusted Simpson's index of species diversity would be 0.35 in the GMNP and 0.33 in the BNP, if both forests were equal in relation to the independent variables (elevation, biomass). In the montane forest, the higher the elevation, the lower the species diversity.

\section{Discussion}

One factor the most important in determining gradients in tree species richness is the relation between the number of species and available energy (Currie and Paquin 1987). Shape of these relations has been described in different ways. Some scientists used to point out the spatial scale problem in researches. At a local scale there is a tendency to describe a humped-back/positive/negative relation (Whittaker et al. 2001; Whittaker 2010) but at geographical scale mainly positive relation (Currie and Paquin 1987; Currie 1991). Pierce (2014) noted that the humped-back relation describes a range of the potential species richness that may develop along the biomass gradient. Belote et al. (2014) suggested that climate-influenced productivity gradients may affect tree species richness patterns. They noted the effect of human land use on very unevenly (along productivity gradient) distribution of natural and managed forests. The main problem with a most fertile forest habitat within temperate zone is that most of such forest were removed and converted into agriculture area. While human use to alter ecosystem by changing the most productive forests into agriculture area, so at least only less productive habitats are more likely to be covered by forest till now.

Although Adler et al. (2011) concluded their studies that species richness - productivity relation is very weak at both local and global scales it is worth to point out though they measured species richness and biomass production across five continents they conducted their studies only on herbaceous vegetation; no forest data were included in their datasets. While Currie and Paquin (1987) stated that this pattern was shaped due to energy unlike Šímová et al. (2011) claimed that the productivity is not the factor affecting species richness at all. Unfortunately it is 
very difficult to discuss this last conclusion, because it is lack of information about row data and on the exact distribution of sample plots within different biomes. It will be very interesting to compare these results with our data, but now it is impossible.

We observed a humped back type of relationship between above-ground biomass and tree-species diversity in natural forest stands all along a gradient of altitude. We therefore decided to analyze data from small plots following an altitude gradient we were able to describe in a much more precise way. In our study, we tried to account for this relationship in line with the elevation gradient involving both lowland and montane natural forests. At the outset, it was noticeable that the two forests were similar as regards the significance of above-ground biomass, despite differences in the range of values for this in the two areas. The stands richest in terms of biomass are dominated by pedunculate oak in the BNP and by European beech in the GMNP.

Data in the literature (Szwagrzyk and Gazda 2007a) revealed that the species diversity of montane forests was lower than that of lowland forests. The nature of this relationship was mainly affected by altitude. Our study revealed that the BNP's forest was characterized by greater evenness. The tree species diversity there (as measured in areas of 200 square metres) was slightly higher where biomass was greater (humped back relation). This means that stands were very diverse on both the small (plot) and the larger (whole Park) scales, ensuring that the values for the diversity index were very similar. Two large areas covered by natural forest did not differ significantly in terms of above-ground biomass, the only difference concerning the range of values within objects: it was possible to find a few plots richer (with greater biomass) in the lowland than in the montane forest.

It is difficult to discuss our results on tree species richness-above-ground biomass relation with other ones mainly because of two main reason: $1^{\circ}$ till now the most numerous data were collected within grasslands (Mittelbach et al. 2001, 2003; Adler et al. 2011; Fraser et al. 2014) $2^{\circ}$ a lot of forest data were originated mainly from tropical forests (Chisholm et al. 2013). There are only a few papers on data collected within different biomes, to combine data of different plant communities (Morin et al. 2011). Morin et al. (2011) stated that species rich forests achieved greater productivity than the most productive forest dominated only by one species; however, large differences were evident across sites. Of course forest communities there are not only trees, however the diversity of the tree canopy affects forest floor diversity by modifying resource availability. In temperate forests, herbs contribute a lot to total plant species richness (Vockenhuber et al. 2011), but herbaceous plant species richness increases with increasing tree diversity.

To gain a better understanding of the relationship between tree-species richness and productivity, we should seek to understand the effects of the different component variables (Körner 2007; Whittaker 2010; Zhang et al. 2012). It is necessary to pay attention here to the spatial and temporal scales of processes shaping this relationship, and to conduct long-term research with a view to explaining this relationship. This is far from easy, however. First, because of the origin of the studied communities, and second because of the roles of, and expectations for, these objects. From a conservationist's point of view it is most important that biodiversity be maintained, while from a forest manager's point of view it is the highest productivity of the given habitat that is crucial.

\section{Conclusions}

The work carried out confirmed our first hypothesis, while failing to sustain the second and third ones. This is to say that the above-ground biomass in natural forests is correlated with tree-species diversity (irrespective therefore of the kind of forest), albeit with the relationship being a humped back one, in contradiction to what had been anticipated.

The results of this study are important, both for the nature conservation and for forest management planning. This reflects the findings or suppositions that:

- forest biodiversity is manifested differently in different natural forests, since lowland forests are diverse on both the small and larger scales, while montane forests are more diverse on the wider scale than on the scale of the given plot,

- the maintenance of biodiversity in forests signifies different challenges, being dependent on the type of a forest (lowland vs. montane), and not automatically denoting that forest is to be made richer every time and within every patch,

- in a managed forest, the species diversity can be raised through a gradual increasing in the share of tree species occurring there naturally, but constrained in the past by forest management, and/ or past or present damage inflicted by herbivores (Miścicki and Żurek 1995; Miścicki 1996),

- species richness can exist on a small spatial scale, meaning that management can ensure the presence of many tree species within individual stands, making it unnecessary for species diversity to be increased through the establishment of a complex of stands each dominated by other species, but with a relatively poor composition. 


\section{Acknowledgements}

This work gained partial support from the Polish National Scientific Centre (grant NCN 2011/01/B/ ST10/07615 to Anna Gazda and Kazimierz Chwistek), as well as the Ministry of Science and Higher Education (grant N N309 111937 to Stanisław Miścicki).

\section{References}

Adler P.B., Seabloom E.W., Borer E.T., Hillebrand H., Hautier Y., Hector A., Harpole W.S., O'Halloran L.R., Grace J.B., Anderson M., Bakker J.D., Biederman L.A., Brown C.S., Buckley Y.M., Calabrese L.B., Chu Ch.-J., Cleland E.E., Collins S.L., Cottingham K.L., Crawley M.J., Damschen E.I., Davies K.F., DeCrappeo N.M., Fay P.A., Firn J., Frater P., Gasarch E.I., Gruner D.S., Hagenah N., Lambers J.H.R., Humphries H., Jin V.L., Kay A.D., Kirkman K.P., Klein J.A., Knops J.M.H., La Pierre K.J., Lambrinos J.G., Li W., MacDougall A.S., McCulley R.L., Melbourne B.A., Mitchell C.E., Moore J.L., Morgan J.W., Mortensen B., Orrock J.L., Prober S.M., Pyke D.A., Risch A.C., Schuetz M., Smith M.D., Stevens C.J., Sullivan L.L., Wang G., Wragg P.D., Wright J.P., Yang L.H.. 2011. Productivity Is a Poor Predictor of Plant Species Richness. Science 333: 1750-1753.

Belote R.T., Aplet G.H. 2014. Land protection and timber harvesting along productivity and diversity gradients in the Northern Rocky Mountains. Ecosphere 5 (2): 17

Bolibok L., Brzeziecki B. 2000. An analysis of selected allometric relationships for the main tree species of the Białowieża National Park. Sylwan 144: 73-81.

Boucher-Lalonde V., Morin A., Currie D.J. 2012. How are tree species distributed in climatic space? A simple and general pattern. Global Ecology and Biogeography 21: 1157-1166.

Caspersen J.P., Pacala S.W. 2001. Successional diversity and forest ecosystem function. Ecological Research 16: 895-903.

Chen H.Y.H., Klinka K., Mathey A.H., Wang X., Varga P., Chourmouzis C. 2003. Are mixed-species stands more productive than single-species stands: an empirical test of three forest types in British Columbia and Alberta. Canadian Journal of Forest Research 33: 1227-1237.

Chisholm R.A., Muller-Landau H.C., Abdul Rahman K., Bebber D.P., Bin Y., Bohlman S.A., Bourg N.A., Brinks J., Bunyavejchewin S., Butt N., Cao H., Cao M., Cárdenas D., Chang L.-W., Chiang J.-M., Chuyong G., Condit R., Dattaraja H.S., Davies S., Duque A., Fletcher C., Gunatilleke N., Gunatilleke S., Hao Z., Harrison R.D., Howe R., Hsieh C.-
F., Hubbell S.P., Itoh A., Kenfack D., Kiratiprayoon S., Larson A.J., Lian J., Lin D., Liu H., Lutz J.A., Ma K., Malhi Y., McMahon S., McShea W., Meegaskumbura M., Mohd. Razman S., Morecroft M.D., Nytch C.J., Oliveira A., Parker G.G., Pulla S., Punchi-Manage R., Romero-Saltos H., Sang W., Schurman J., Su S.-H., Sukumar R., Sun I.F., Suresh H.S., Tan S., Thomas D., Thomas S., Thompson J., Valencia R., Wolf A., Yap S., Ye W., Yuan Z., Zimmerman J.K. 2013. Scale-dependent relationships between tree species richness and ecosystem function in forests. Journal of Ecology 101: 1214-1224.

Currie D.J. 1991. Energy and large-scale patterns of animal- and plant-species richness. American Naturalist 137: 27-49.

Currie D.J., Paquin V. 1987. Large-scale biogeographical patterns of species richness of trees. Nature 329: 326-327.

DeClerck F.A.J., Barbour M.G., Sawyer J.O. 2005. Resource use efficiency as a function of species richness and stand composition in upper montane conifer forests of the Sierra Nevada. Journal of Vegetation Science 16: 443-452.

Faliński J.B. 1986. Vegetation dynamics in temperate lowland primeval forests: ecological studies in Białowieża Forest. Junk Publishers, Dordrecht.

Fraser L.H., Jentsch A., Sternberg M. 2014. What drives plant species diversity? A global distributed test of the unimodal relationship between herbaceous species richness and plant biomass. Journal of Vegetation Science 25: 1160-1166.

Giel M., Glapa M., Szewczyk J., Szwagrzyk J. 2001. Comparative analysis of tree habit on the example of some tree species from Białowieża National Park and Niepołomice Forest. Sylwan 145: 31-42.

Holeksa J., Saniga M., Szwagrzyk J., Czerniak M., Staszyńska K., Kapusta P. 2009. A giant tree stand in the West Carpathians - An exception or a relic of formerly widespread mountain European forests? Forest Ecology and Management 257: 1577-1585.

Jacob M., Leuschner C., Thomas F.M. 2010. Productivity of temperate broad-leaved forest stands differing in tree species diversity. Annals of Forest Science 67: 503.

Keeling H.C., Phillips O.L. 2007. The global relationship between forest productivity and biomass. Global Ecology and Biogeography 16: 618-631.

Körner Ch. 2007. The use of 'altitude' in ecological research. Trends in Ecology \& Evolution 22: 569-574.

Krebs C.J. 1994. Ecology: The experimental analysis of distribution and abundance. $5^{\text {th }}$ ed. Harper Collins College Publishers, NY, US.

Krzysik F. 1974. Wood science. Państwowe Wydawnictwo Naukowe, Warszawa. 
Legendre P., Legendre L. 2012. Numerical ecology, third English edition. Elsevier, Amsterdam, Oxford.

Magurran A.E. 2004. Measuring Biological Diversity. Wiley-Blackwell, Oxford, UK.

McCain C.M., Grytnes J.A. 2010. Elevational gradients in species richness. Encyclopedia of Life Sciences, John Wiley \& Sons, Ltd.

Miścicki S. 1996. Forest regeneration and its damage by herbivorous ungulates in the Białowieża National Park. In: Biodiversity protection of the Białowieża Primeval Forest. Paschalis P., Zajączkowski S. (eds.). Fundacja Rozwój SGGW, Warszawa, pp. 91-108.

Miścicki S., Żurek, Z. 1995. Inventorying forest regeneration and damage done to it by deer in the Gorce National Park. Sylwan 139: 53-69.

Mittelbach G.G., Scheiner S.M., Steiner C.F. 2003. What is the observed relationship between species richness and productivity? Reply. Ecology 84: 3390-3395.

Mittelbach G.G., Steiner C.F., Scheiner S.M., Gross K.L., Reynolds H.L., Waide R.B., Willig M.R., Dodson S.I., Gough L. 2001. What is the observed relationship between species richness and productivity? Ecology 82: 2381-2396.

Morin X., Fahse L., Scherer-Lorenzen M., Bugmann H. 2011. Tree species richness promotes productivity in temperate forests through strong complementarity between species. Ecology Letters 14: 1211-1219.

Mouquet N., Moore J.L., Loreau M. 2002. Plant species richness and community productivity: why the mechanism that promotes coexistence matters? Ecology Letters 5: 56-65.

Nogués-Bravo D., Araújo M.B., Romdal T., Rahbek C. 2008. Scale effects and human impact on the elevational species richness gradients. Nature 453: 216-219.

Pierce S. 2014. Implications for biodiversity conservation of the lack of consensus regarding the humped-back model of species richness and biomass production. Functional Ecology 28: 253 257.
Rahbek C. 2005. The role of spatial scale and the perception of large-scale species-richness patterns. Ecology Letters 8: 224-239.

Šímová I., Storch D., Keil P., Boyle B., Phillips O. L., Enquist B. J. 2011. Global species-energy relationship in forest plots: role of abundance, temperature and species climatic tolerances. Global Ecology and Biogeography 20: 842-856.

Szwagrzyk J., Gazda A. 2007a. Above-ground standing biomass and tree species diversity in natural stands of Central Europe. Journal of Vegetation Science 18: 555-562.

Szwagrzyk J., Gazda A. 2007b. Species diversity of trees and productivity of forest ecosystems. Wiadomości Ekologiczne 53: 123-138.

Vilà M., Vayreda J., Comas L., Ibáñez J.J., Mata T., Obón B. 2007. Species richness and wood production: a positive association in Mediterranean forests. Ecology Letters 10: 241-250.

Vockenhuber E.A., Scherber C., Langenbruch C., Meissner M., Seidel D., Tscharntke T. 2011. Tree diversity and environmental context predict herb species richness and cover in Germany's largest connected deciduous forest. Perspectives in Plant Ecology, Evolution and Systematics 13: 111-119.

Waide R.B., Willig M.R., Steiner C.F., Mittelbach G., Gough L., Dodson S.I., Juday G.P., Parmenter R. 1999. The relationship between productivity and species richness. Annual Review of Ecology and Systematics 30: 257-300.

Whittaker R.J., Heegaard E. 2003. What is the observed relationship between species richness and productivity: comment. Ecology 84: 33843390.

Whittaker R.J., Willis K.J., Field R. 2001. Scale and species richness: towards a general, hierarchical theory of species diversity. Journal of Biogeography 28: 453-470.

Whittaker R.J. 2010. Meta-analyses and mega-mistakes: calling time on meta-analysis of the species richness-productivity relationship. Ecology 91: 2522-2533.

Zhang Y., Chen H.Y.H., Reich P.B. 2012. Forest productivity increases with evenness, species richness and trait variation: a global meta-analysis. Journal of Ecology 100: 742-749. 